\title{
The tropical pocket gopher (Geomys tropicalis) on the brink of extinction
}

\section{La tuza tropical (Geomys tropicalis), al borde de la extinción}

\author{
Fernando A. Cervantes ${ }^{1 *}$ \\ 'Colección Nacional de Mamíferos, Departamento de Zoología, Instituto de Biología, Universidad Nacional Autónoma de México. \\ Ciudad Universitaria, C. P. 04510. Ciudad de México, México. E-mail: fac@ib.unam.mx (FAC). \\ *Corresponding author
}

\begin{abstract}
The tropical pocket gopher (Geomys tropicalis) is a rodent with fossorial habits that lives only in a small region of the southern coastal area of Tamaulipas, México. It is a distinctive mammal with unique morphological, genetic and ecological characteristics that makes it a relevant species. Unfortunately, it is not studied or monitored and its existence in the region is unknown. Currently, the growth of agriculture, urbanization and industrialization in the vicinity of the cities of Altamira and Tampico have severely fragmented and reduced its habitat, which is why it is considered that its population is continuously decreasing; consequently, it is listed as a species at high risk of extinction. Previous estimates of its potential distribution indicate the existence of areas surrounding its original distribution with appropriate abiotic characteristics for its presence where it can be protected. Therefore, it is urgent that the public be aware of this situation and that residents, authorities, academics and non-governmental organizations join forces proposing and activating actions for their conservation.
\end{abstract}

Key words: Altamira; conservation; Geomyidae; habitat loss; mound; Tampico; underground.

La tuza tropical (Geomys tropicalis) es un roedor de hábitos fosoriales que habita únicamente una pequeña región de la zona costera del sur de Tamaulipas, México. Es un mamífero con características morfológicas, genéticas y ecológicas únicas que lo hace una especie relevante. Desafortunadamente, no se estudia ni monitorea y se desconoce su existencia en la región. Actualmente el crecimiento de las prácticas de agricultura, urbanización e industrialización de las ciudades de Altamira y Tampico han fragmentado y reducido severamente su hábitat y se considera que su población disminuye continuamente; en consecuencia, se le clasifica como especie en alto riesgo de extinción. Estimaciones previas sobre su distribución potencial indican la existencia de áreas aledañas a su distribución original con características abióticas apropiadas para su presencia en donde puede ser protegida. Por lo tanto, es urgente que el público en general conozca esta situación y que pobladores, autoridades, académicos y organizaciones no gubernamentales unan esfuerzos para proponer y activar acciones para su conservación.

Palabras clave: Altamira; conservación; Geomyidae; montículo; pérdida de hábitat; subterráneo, Tampico.

(c) 2021 Asociación Mexicana de Mastozoología, www.mastozoologiamexicana.org

The tropical pocket gopher (Geomys tropicalis) is a rodent (Family Geomyidae) described at the beginning of the 20th century with specimens collected in Altamira, Tamaulipas, by Edward A. Goldman (Figure 1a). Originally it was called "Tamaulipas gopher" and considered taxonomically to correspond to a subspecies of Geomys personatus (G. p. tropicalis; Goldman 1915); almost 50 years later, it was recognized as a taxonomic entity at the species level (G. tropicalis; Álvarez 1963). This species lives exclusively in México and has no subspecies (Figure 2a). Currently, 105 years after its description, it continues to be a practically unknown mammal in danger of extinction, mainly due to the destruction of its habitat. Therefore, the objectives of this document are to disclose its existence, report on the critical state of its population and stimulate sectors of society to initiate actions in favor of its conservation.

Characteristics of the tropical pocket gopher. The tropical pocket gopher is medium in size and adapted to live almost all the time below the surface of the soil (fossorial). Its face is short and broad and its fur is velvety, short and with cinnamon to cinnamon buff color that becomes lighter towards the ventral parts; it has highly sensory whiskers and its tail is hairless (Baker and Williams 1974). The dark and relatively quiet environment of the interior of its galleries and narrow spaces have selected adaptations in all species of pocket gophers such as the presence of proportionally small eyes and ears. Adult specimens measure an average of $245.2 \mathrm{~mm}$ in total length, with males $(255.9 \mathrm{~mm}$ ) slightly larger than females (234.5 mm; Williams and Genoways 1977). Males are, on average, slightly heavier than females (268.3 and $189.4 \mathrm{gr}$, respectively); its tail measures $82 \mathrm{~mm}$ on average and the right hind leg $33.8 \mathrm{~mm}$ (Álvarez 1963). Its original geographic distribution is allopatric in relation to other species of pocket gophers (Figure 2a).

The pectoral musculature and the developed claws of the front legs allow it to dig long underground galleries that it uses as burrows (Figure 1b). They have five toes on each leg and calluses on the palm of the forelimbs that make it easier for them to push the dirt. Like other pocket gopher species, it has an external pouch or pocketshaped fold of skin on each cheek where it stores freshly cut food to reduce the time of exposure to possible predators when it collects food outside its burrow (Hafner 2016). This pocket gopher is most active at dawn and dusk and 
feeds mainly on aerial parts such as stems and leaves, roots and bulbs of herbaceous plants; it also consumes soft, thin stems of shrubs (Bradford 2017).

Its powerful teeth consist of 20 teeth that grow continuously due to their intense wear. It has four large incisors with a dense layer of frontal enamel that provides additional toughness (Figure 1c). This allows it to cut through all kinds of plant matter when it surfaces; even using them to "break" the earth when digs. The remaining 16 teeth are relatively flat oval molariforms that use to finely grind the materials on which it feeds on (Hafner 2016).

Evidence of their presence are the mounds of earth on the surface of the soil that are easily visible and recognizable. These are unmistakable traces of earth that they extract from the construction of underground burrows and that accumulate at the entrance and exit of their tunnels (Bradford 2017). At the top of some fresh mounds one can see the trace of a small plugged hole through which the gopher appeared for the last time. They are generally found in natural open fields and growing areas; they are rarely found on stony or wooded areas. In other species of pocket gophers of the genus Geomys, it is common to

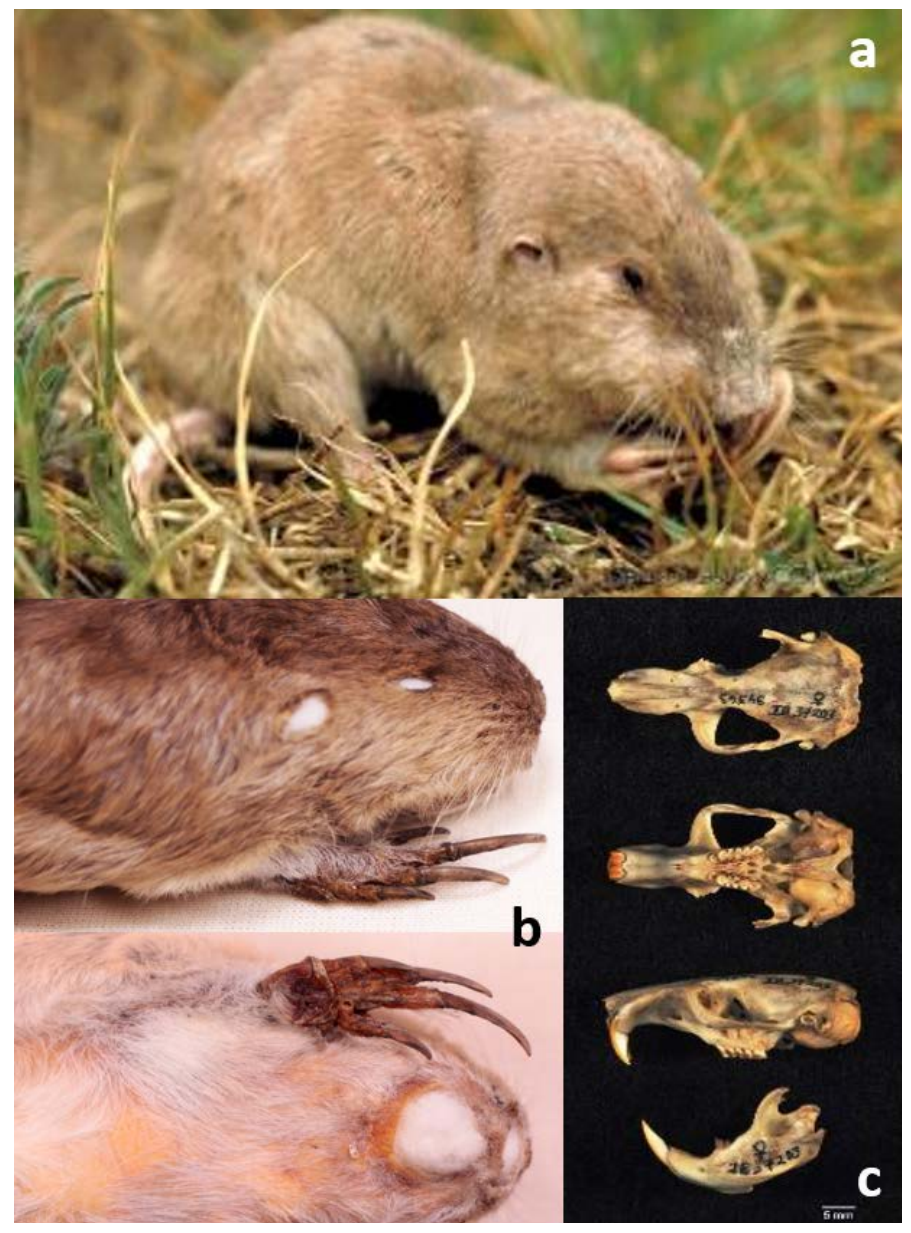

Figure 1. a) The tropical pocket gopher (Geomys tropicalis; photograph by G. Ceballos from the Image Bank of the Comisión Nacional para el Conocimiento y Uso de la Biodiversidad, México). b) Right lateral and ventral views of the anterior part of the body of G. tropicalis. Note the development of the claws (photograph by K. E. Juárez). c) Dorsal, ventral and lateral views of the skull and mandible of G. tropicalis (collection catalog number: CNMA_37203, adult female). Note the large front incisor teeth and the thick orange enamel coating on the front surface (photograph by K. E. Juárez). observe up to a dozen of these mounds in natural areas of around $40-50 \mathrm{~m}^{2}$ (Hafner 2016). In all the pocket gopher species of the Geomyidae family, the adults are solitary individuals, so this condition normally corresponds to the activity of a single adult individual.

Its natural habitat is the coastal plain of southern Tamaulipas (Figure 2b), with deep sandy soil and typical arid adapted vegetation. The ground is covered with halophile vegetation, including herbaceous plants and grasses; in some areas the landscape also contains shrub forms and isolated trees such as mesquite (Prosopis), cactus (Opuntia), and acacia (Vachellia; Arriaga et al. 2000).

From a genetic point of view, this pocket gopher is also unique and distinctive. Its karyotype consists of a diploid chromosome number $(2 n)$ of 38 and a fundamental number (FN) of 72 (Davis et al. 1971). This set of genetic information is comparatively different from that of other species of pocket gopher by its low number of chromosomes and by the biarmed condition (two arms on each side of the centromere) of the autosomes (36 non-sexual chromosomes); in addition, several of the subtelocentric chromosomes have secondary constrictions. The analysis of its " $\mathrm{G}$ " and " $\mathrm{C}$ " chromosome bands showed that this chromosomal arrangement is the product of a complex chromosomal evolution not observed in other species of its genus, where the main probable mechanism was many centric fusions of acrocentric chromosomes (Davis et al. 1971).

Biological variation among species of the genus Geomys is moderate, so their phylogenetic relationships have been difficult to assess, even using morphometric, chromosomal and genetic data (Davis et al. 1971). However, a general opinion was that the chromosomal characteristics of $G$. tropicalis were the strongest criteria for the continuous recognition of the tropical pocket gopher as an independent evolutionary lineage sufficiently different from other species of the genus Geomys (Jolley et al. 2000).

The use of molecular markers in mammal systematics provided phylogenetic information revealing that G. tropicalis is part of the group of species of the Texas pocket gopher (G. personatus), together with Strecker's pocket gopher (G. streckeri), and Attwater's pocket gopher (G. attwateri; Sudman et al. 2006). This research approach using mitochondrial and nuclear genes indicated that the phylogenetic position of the tropical pocket gopher places it as the sister taxa of a subspecies of the Texas pocket gopher (G. personatus davisi; Chambers et al. 2009). Additional comparisons between these two species showed that some of their genes share identical nucleotide sequences, which supports the hypothesis of their common ancestry; they also identified other unique sequences of the evolutionary lineage of each species. This molecular process led to a low genetic distance between this pair of species compared to that recorded for other combinations of sister species of the personatus species group; inclusive, even more, the topology of the phylogenetic reconstruction suggests that the tropical pocket gopher could be recognized as part of G. personatus (Chambers et al. 2009). 
However, the decision to recognize $G$. tropicalis as a complete taxonomic and evolutionary entity standed also because its geographic distribution is completely isolated from any other Geomys species, and because G. personatus davisi is proposed to be promoted to species status, which would leave the phylogenetic recognition of $G$. tropicalis as a complete species unrestricted (Chambers et al. 2009). To better support these hypotheses, a broad sampling of genes would have to be carried out, examining a greater number of individuals and from different geographical origins.

Ecological importance. The tropical pocket gopher is relevant for the structure and function of its ecosystem (Huntly and Inouye 1988). By removing the soil, this rodent promotes the dynamics of the physical and chemical characteristics of the soil and favors the presence of wild plants (primary producers of the ecosystem; Mielke 1977). Likewise, it contributes to the regulation of plant populations due to the selective removal of plants that it carries out for their food and the collection of plant material for nesting (Hafner 2016).

On the other hand, as part of the food web in its habitat, this pocket gopher is predated by snakes (Crotalus), owls (Bubo), weasels (Mustela), foxes (Urocyon) and skunks (Mephitis; Vaughn 1961; Hafner 2016). As in other species of pocket gophers, G. tropicalis becomes potential prey for predators when it emerges from its burrow to search for food at the ground's surface (Hafner 2016). Additionally, its abandoned tunnels generate protection and shelter spaces for many species of invertebrates (i.e., worms, spiders, crickets, mealybugs, ants, snails, among others) and vertebrates, i.e., mice (Peromyscus), squirrels (Urocitellus), toads (Bufo), lizards (Cnemidophorus), snakes (Pituophis); Vaughn 1961;
González-Romero 2018). The presence of all these species, in turn, generates predator-prey relationships between them (Vaughn 1961). Consequently, the tunnels of abandoned $G$. tropicalis burrows can also become foraging routes for small predators.

Therefore, tropical pocket gophers are essential to contribute to the presence of different trophic levels of its ecosystem and the necessary energy flow. The biotic part of its habitat has a delicate and fragile ecological balance on which all species of halophile vegetation and associated fauna depend, including G. tropicalis.

Extinction risk. One of the problems for the conservation of many species at some risk of extinction is that they go unnoticed in their natural environment because they are not known to the public. This produces that what is not known is not investigated and, therefore, is not preserved and disappears. This circumstance greatly affects the tropical pocket gopher, because by not knowing its risk of extinction, it can be lost without realizing it.

The Mexican federal government considers the tropical pocket gopher as a mammal placed in the category of "Threatened" (Trujillo-Segura 2019). This means that this rodent "could find itself in danger of disappearing in the short or medium term, if the factors that negatively affect its viability continue to operate, by causing the deterioration or modification of its habitat or directly reducing the size of its populations" (SEMARNAT 2020).

On the other hand, the International Union for the Conservation of Nature (IUCN) has kept the tropical pocket gopher in one of its categories of extinction risk for many years now. During the period 2008-2017, this organiza-

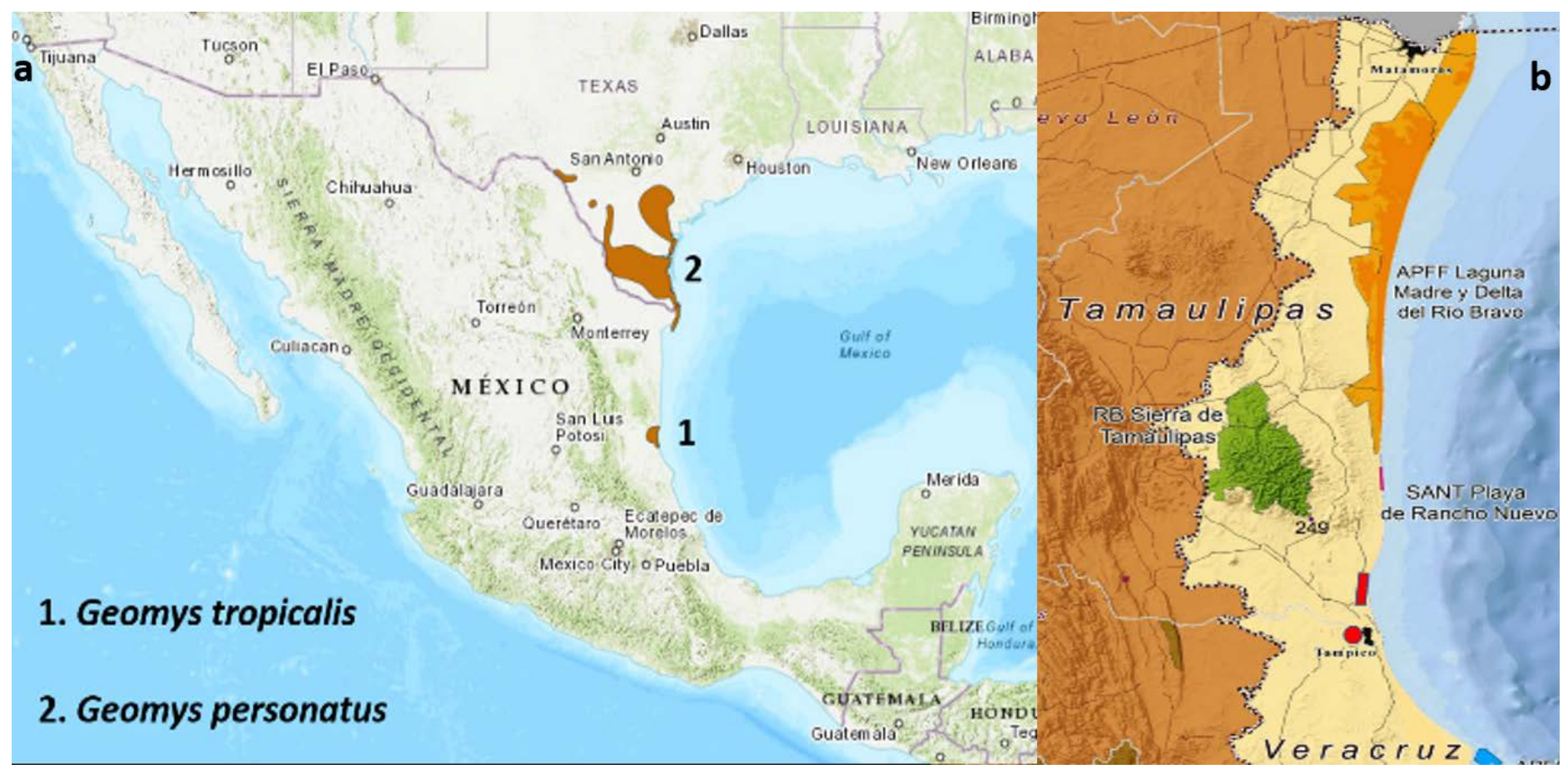

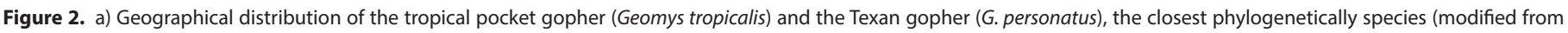

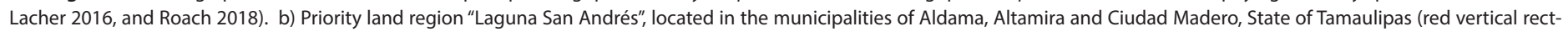


areas are also shown in the same federal entity: a Sanctuary (SANT), a Flora and Fauna Protection Area (APFF), and a Biosphere Reserve (RB; modified from CONANP 2019). 
tion placed G. tropicalis in the category of "critical danger of extinction". In its last assessment in 2018, the IUCN classified the tropical pocket gopher as "endangered" (Roach 2018). The criteria for making this decision were that its geographic distribution area is less than $5,000 \mathrm{~km}^{2}$ and that its area of occupation is less than $150 \mathrm{~km}^{2}$; both small areas. Also, that their populations are fragmented, isolated and associated with a very specific type of habitat.

This scenario by itself is a threat due to intrinsic factors of the species related to population size, distributional area and isolation; a severe problem is the decrease in gene flow and the loss of genetic variation. If there is not a minimum number of reproductive adults and connections between populations, there is a risk that interbreeding and genetic drift will affect the level of genetic variability necessary for populations of this species to remain healthy in their natural habitat. Especially now that wild species require more than ever to conserve their full genetic potential to successfully face the ongoing challenges of climate change.

Additionally, the IUCN highlighted that its environment suffers a continuous degradation in quantity and quality. Agriculture and industrialization are eliminating their area of occupation, which is rapidly contributing to the fragmentation of their habitat. Various sites that have been reported in the past by field biologists as locations of occurrence of the tropical pocket gopher (e.g., Altamira; $1 \mathrm{mi}$ S Altamira; $2.4 \mathrm{mi}$ S Altamira; $2.5 \mathrm{mi}$ SSE Altamira; $2.5 \mathrm{mi}$ SW Altamira; $1 \mathrm{mi}$ N Tampico; $10 \mathrm{mi}$. NW Tampico; Williams and Genoways 1977), have now become urban areas of the cities of Altamira and Tampico, Tamaulipas. Consequently, the IUCN mentioned that $G$. tropicalis could return to the maximum level of extinction risk: "critical danger of extinction" (Critically Endangered), as its presence continues to decrease and its populations remain isolated (Roach 2018). However, they think it is necessary to gather more information about their population status before making that decision.

Also reporting to the IUCN, a group of specialists, nationals and foreigners, from the Small Mammal Specialist Group and the Conservation Planning Specialist Group led a workshop in Puebla in 2018 to gather available information on the conservation of Mexican small mammals, identify their research priorities and plan mechanisms for the implementation of actions for their conservation (SMSG 2018). They identified 17 Mexican rodent species as critically endangered, including G. tropicalis. However, they selected only 6 for the development of conservation strategies and their financial support; among the selection criteria used, the phylogenetic distinction, population size and trend, number of localities and threats, among others, stand out. Although G. tropicalis shared the highest "urgency value" result with other species, the "feasibility value" was not the highest, nor was the "number of other threatened species that would benefit" value. Therefore, the tropical pocket gopher was out in 8th place.

There are no published studies on the biology of G. tropicalis in almost 20 years, nor has its presence been docu- mented in its original range; it has not been mentioned in any technical or scientific disclosure paper, except for the report by Fernández et al. (2014), who claimed to have seen in 1993 only a few small fragments of habitat suitable for G. tropicalis in the surroundings of Altamira, Tamaulipas. Therefore, they agreed to report it as a critically endangered species and recommended urgent distribution and abundance studies to prevent its disappearance.

A detailed updated assessment of the conservation status of this mammal is necessary. It is worrying that no project or program of any sector of society dedicated to this task is publicly known. The evaluation of the risk of extinction of the native species of México must be considered a priority action in terms of the conservation of biodiversity (García-Aguilar et al. 2017). Unfortunately, what does exist is information about other species of pocket gopher and the damage they cause (Hafner 2016), as they are considered a pest species and are fought with unnecessary cruel methods. We should not wait for this situation to be repeated with $G$. tropicalis.

Perspectives. The extinction of native flora and fauna species in their natural habitat continues to be a matter of concern in México in terms of biodiversity conservation. On occasions, a supposed disappearance of a species is reported because in several years it has not been seen or recorded in its natural environment. In other cases, because no one studies them there are no mentions of their existence. These examples almost always refer to species that have a small and little explored geographic distribution.

Such is the case of the Omiltemi rabbit (Sylvilagus insonus) known only from a small area of the cloud forest of Guerrero, México, and declared extinct in 1977 (MacPhee and Fleming 1997). Shortly after, this mammal was searched in its natural habitat and rediscovered (Cervantes et al. 2003). Similarly, the San Quintin kangaroo rat (Dipodomys gravipes), which was known only from a small strip of desert in the northwestern state of Baja California, was considered an extinct species by the Mexican government; in April 2018 it was rediscovered (Tremor et al. 2019). Another case is the Los Tuxtlas shrew (Cryptotis nelsoni), whose presence had never been documented for more than 100 years. It was not until 2002 that its presence was confirmed in the San Martín Tuxtla Volcano, Veracruz (Cervantes and Guevara 2010).

Unfortunately, no recent record has been reported for the tropical pocket gopher, meaning its presence has not been scientifically documented for many years; the most likely reason it is that is not inhabiting the same area where it existed before (Fernández et al. 2014). Available public information indicates that it is an unknown species. The latest evidences of its existence are more than 100 specimens conventionally prepared for scientific study in some American biological collections, which were collected shortly after the year 2000. In all of México, however, there is only one specimen at the National Mammal Collection of the Institute of Biology, National Autonomous University of México (catalog: CNMA37203, female; Figures $1 \mathrm{~b}$ and 1c), reflect- 
ing the ignorance surrounding these species. Although the government of México and the IUCN considered the tropical pocket gopher in some category of risk of extinction, it is not enough with names on paper to save this important and distinctive rodent of Mexican biodiversity from probable extinction.

In principle, it would not be necessary to collect specimens to confirm the taxonomic identity of the species until ensuring that its populations maintain a similar size to that of other pocket gopher species; however, an individual could be captured, somatic measurements and tissue samples for DNA lab work taken, photographed, and released immediately. Next, it would be necessary to verify their presence at short intervals and keep a record for their monitoring.

Protected natural areas: alternative. An alternative to help conserve the tropical pocket gopher is to promote its protection and management in a protected natural area. None of the three federal reserves in the Coastal Plain and Gulf of Mexico region (Sierra de Tamaulipas, Playa de Rancho Nuevo, Laguna Madre and Delta del Río Bravo; CONANP 2016) would be an option, since none coincides with the geographical distribution of $G$. tropicalis.

However, the municipal reserve called "La Vega Escondida", located in the municipality of Tampico, Tamaulipas (De la Garza-Govela 2003), could be a viable option (Figure $2 \mathrm{~b}$ ). It is a special area subject to ecological conservation due to the importance it represents for its biodiversity, which is located northwest of the City of Tampico and coincides with the distribution area of G. tropicalis; this is important because all published field records of the tropical gopher are from Altamira city to the south. By a decree of the municipal authorities it is known that "the inhabitants of the Tampico-Madero-Altamira conurbation, including the users of the lagoons, as well as environmental groups and the scientific community, have expressed interest in establishing a protection regime in at least one part of the lagoon system of the Tamesí River, which allows stopping or limiting the degradation of this ecosystem" (De la GarzaGovela 2003). In addition, as an environmental policy of that level of government, it was known that "The establishment of priority areas for the preservation and restoration of the ecological balance and the care of the sites necessary to ensure the maintenance of the diversity of flora and fauna is of public utility, wild and aquatic fauna, and that it be incorporated at the regional level in efforts to promote and strengthen environmental education" (De la GarzaGovela 2003). If the presence of the tropical pocket gopher is confirmed in that area, this scenario could already be used as a platform to seek support in favor of its protection, counting with the endorsement of an authority and, on the other hand, in a site of its potential distribution.

In addition, the Laguna San Andrés priority terrestrial region could also help conserve the tropical pocket gopher (Figure 2b). Although administratively it is not a protected area, it is a site whose purpose is the ecological conservation of areas of biological richness, highlighting the presence of endemic and threatened species (Arriaga et al. 2000). Even in the designation of this region, the presence of the tropical pocket gopher was considered as one of several criteria to select that place as a priority land region in Tamaulipas (Arriaga et al. 2000). Until now, the presence of the tropical pocket gopher to the north of the city of Altamira has not been documented, but the potential distribution estimated with curatorial records of scientific collections by two different working groups (Ballesteros-Barrera 2016; CeballosGonzález 2008) indicates that the distribution of G. tropicalis almost adjoins Laguna San Andrés, for which it is necessary to carry out inventories to confirm the presence of the tropical pocket gopher in that priority terrestrial region.

At present, a work team made up of students and academics from the Altamira Technological Institute, the Institute of Biology, UNAM, and personnel from some civil organizations have initiated actions to advocate these recommendations. They intend to search and document the presence of the tropical pocket gopher in the municipalities of Altamira and Tampico, characterize its current habitat, factors that modify it, and percentage of loss thereof.

Conclusions. The tropical pocket gopher Geomys tropicalis is an exclusively Mexican species with unique characteristics and its presence in its ecosystem is necessary. Unfortunately, it is an endangered species and its continuous existence is not warranted. However, there are options to start planning actions aimed at protecting this species. It should begin by carrying field work to confirming its existence in its original range and, without a doubt, the active participation of personnel from the state reserve and the priority land region mentioned above should be incorporated. Identifying the presence of the tropical pocket gopher would not be difficult as finding mounds of earth in the field would reveal its presence; they are unmistakable traces that would allow us to update our knowledge of their distributional area.

Thereupon it is necessary to summon various sectors of society to plan and formally participate in actions aimed at the investigation of G. tropicalis for its conservation and management. The authorities of the three levels of government, local people, the academic sector and non-governmental organizations should be the main actors in an initiative of this nature. It is therefore urgent to disseminate both the knowledge of the existence of the tropical pocket gopher and its status as a species at risk of extinction and promote citizen participation in this matter. If this paper helps to achieve these objectives, it will have served its purpose.

\section{Acknowledgements}

I am grateful to G. Cruz, K. E. Juárez, G. Ceballos, CONANP and $C O N A B I O$ for the loan of the images used in this paper. I also thank the anonymous reviewers for their valuable constructive criticisms. I respectfully dedicate this contribution to the memory of the great naturalist and mammalogist William López-Forment Conradt, esteemed teacher, 
colleague and friend; his work for the knowledge and conservation of Mexican wildlife left an indelible mark.

\section{Literature cited}

Álvarez, T. 1963. The recent mammals of Tamaulipas, México. University of Kansas Publications, Museum of Natural History 14:363-473.

Arriaga, L., J. M. Espinoza, C. Aguilar, E. Martínez, L. Gómez, AND E. LoA (coords.). 2000. Regiones terrestres prioritarias de México. Comisión Nacional para el Conocimiento y Uso de la Biodiversidad. https://www.conabio.gob.mx/conocimiento/ regionalizacion/doctos/terrestres.html. Downloaded on 30 May 2020.

BakeR, R. J., AND S. L. Williams. 1974. Geomys tropicalis. Mammalian Species 35:1-4.

Ballesteros-Barrera, C. 2016. Distribución potencial de las especies de mamíferos con distribución restringida presentes en México. Final project report JM053, SNIB-CONABIO. México City, México. https://www.conabio.gob.mx/institucion/ proyectos/resultados/InfJM053.pdf. Downloaded on 30 May 2020.

BradFord, A. 2017. Facts about gophers. https://www.livescience.com/57623-gopher-cts.hml. Downloaded on 3 September 2020.

Ceballos-González, J. G. 2008. Modelado de la distribución de las especies de mamíferos de México para un análisis GAP. Final project report DS006, SNIB-CONABIO. México City, México. https://www.conabio.gob.mx/institucion/proyectos/resultados/InfDS006.pdf. Downloaded on 30 May 2020.

Cervantes, F. A., And L. Guevara. 2010. Rediscovery of the critically endangered Nelson's small-eared shrew (Cryptotis nelsoni), endemic to Volcán San Martín, Eastern México. Mammalian Biology 75:451-454.

Cervantes, F. A., C. Lorenzo, and F. X. González-Cózatl 2003. The Omiltemi rabbit (Sylvilagus insonus) is not extinct. Mammalian Biology 68:1-4.

Chambers, R. R., P. D. Sudman, and R. D. Bradley. 2009. A phylogenetic assessment of pocket gophers (Geomys): evidence from nuclear and mitochondrial genes. Journal of Mammalogy 90:537-547.

Conanp (Comisión Nacional de Áreas Naturales Protegidas). 2016. Sistema Nacional de Áreas Protegidas (SINAP). https:// www.gob.mx/conanp/acciones-y-programas/sistema-nacional-de-areas-protegidas-sinap. Downloaded on 25 June 2020. conanp (Comisión Nacional de Áreas Naturales Protegidas). 2019. Mapas de las regiones CONANP. Región Planicie Costeras y Golfo de México. https://sig.conanp.gob.mx/website/ pagsig/mapas/regiones/region golfo.pdf. Downloaded on 25 June 2020.

Davis, B. L., S. L. Williams, and G. López. 1971. Chromosomal studies of Geomys. Journal of Mammalogy 52:617-620.

De la Garza-Govela, J. J. 2003. Acuerdo Municipal mediante el cual se declara Área Natural Protegida, clasificada como Zona Especial Sujeta a Conservación Ecológica, al área denominada "La Vega Escondida" ubicada en el Municipio de Tampico, Tamaulipas. Periódico Oficial 128:5-14.

Fernández, J. A., M. S. Hafner, D. J. Hafner, and F. A. Cervantes. 2014. Conservation status of rodents of the families Geomy- idae and Heteromyidae of Mexico. Revista Mexicana de Biodiversidad 85:576-588.

García-Aguilar, M., J. Luévano Esparza, and H. de la Cueva. 2017. La fauna nativa de México en riesgo y la NOM-059: ¿Están todos los que son y son todos los que están? Acta Zoológica Mexicana 33:188-198.

Goldman, E. A. 1915. Five new mammals from Mexico and Arizona. Proceedings of the Biological Society of Washington 28:133-137.

GonzÁlez-Romero, A. 2018. Diversidad y madrigueras de roedores. Instituto Nacional de Ecología. https://www.inecol.mx/inecol/ index.php/es/ct-menu-item-25/ct-menu-item-27/17-cienciahoy/1092-diversidad-y-madrigueras-de-roedores. Downloaded on 3 September 2020.

HafNer, M. S. 2016. Family Geomyidae (pocket gophers). Pp. 234-265 in Lagomorphs and Rodents I. Handbook of mammals of the World, vol. 6 (Wilson, D. E., T. E. Lachert, and R. A. Mittermeier, eds.). Lynx Edicions, Conservation International and IUCN. Barcelona, Spain.

Huntly, N., AND R. Inouye. 1988. Pocket Gophers in Ecosystems: Patterns and Mechanisms. Bioscience 38:786-793

Jolley, T. W., R. L. Honeycutt, and R. D. Bradley. 2000. Phylogenetic relationships of pocket gophers (genus Geomys) based on the mitochondrial 12S rRNA gene. Journal of Mammalogy 81:1025-1034.

LACHER, T. 2016. Texan pocket gopher. Geomys personatus. The IUCN Red List of Threatened Species. Version 2017.3. https:// www.iucnredlist.org. Downloaded on 15 July 2020.

MacPhee, R., AND C. Fleming. 1997. Brown-eyed, milk-giving... losing mammals since A.D. 1500. Natural History 106:84-85.

MIELKE, H. W. 1977. Mound building by pocket gophers (Geomyidae): their impact on soils and vegetation in North America. Journal of Biogeography 4:171-180.

RoACH, N. 2018. Tropical pocket gopher. Geomys tropicalis. The IUCN Red List of Threatened Species. Version 2017.3. www.iucnredlist.org. Downloaded on 16 July 2020.

Semarnat (Secretaría de Medio Ambiente y Recursos NaturaLES). 2020. Conoce las categorías de riesgo para las especies silvestres terrestres y acuáticas. https://www.gob.mx/ semarnat/articulos/conoce-las-categorias-de-riesgo-paralas-especies-silvestres-terrestres-y-acuáticas. Downloaded on 25 June 2020.

SMSG (Small Mammal Specialist Group). 2018. Mexican Small Mammal Assessment, Prioritization and Conservation Planning Workshop. Small Mammal Specialist Group, SSC, IUCN. Puebla, México.

Sudman, P. D., J. K. Wickliffe, P. Horner, And M. J. Smolen. 2006. Molecular Systematics of pocket gophers of the genus Geomys. Journal of Mammalogy 87:668-676.

Trujillo-Segura, J. C. J. 2019. MODIFICACIÓN del Anexo Normativo III, Lista de especies en riesgo de la Norma Oficial Mexicana NOM-059-SEMARNAT-2010, Protección ambiental-Especies nativas de México de flora y fauna silvestres-Categorías de riesgo y especificaciones para su inclusión, exclusión o cambio-Lista de especies en riesgo, publicada el 30 de diciembre de 2010. Diario Oficial de la Federación. 14 de noviembre.

Tremor, S., S. Vanderplank, and E. Mellink. 2019. The San Quintín Kangaroo Rat is not extinct. Bulletin Southern California Academy of Sciences 118:71-75. 
VAughn, T. A. 1961. Vertebrates Inhabiting Pocket Gopher Burrows in Colorado. Journal of Mammalogy 42:171-174.

Williams, S. L., AND H. H. Genoways. 1977. Morphometric variation in the tropical pocket gopher (Geomys tropicalis). Annals of Carnegie Museum 46:245-264.

Associated editor: Beatriz Bolívar-Cimé

Submitted: November 16, 2020; Reviewed: January 4, 2021.

Accepted: January 14, 2021; Published on line: January 25, 2021. 